\title{
PENGARUH PROFESIONALISME TERHADAP PRODUKTIVITAS PEGAWAI PADA BADAN PUSAT STATISTIK PROVINSI SULAWESI SELATAN
}

\section{THE EFFECT OF PROFESSIONALISM ON EMPLOYEE WORK PRODUCTIVITY IN THE STATISTIC CENTER OF SOUTH SULAWESI PROVINCE}

\author{
Usman $^{1}$, Yanti $^{2}$ \\ Sekolah Tinggi Keguruan dan Ilmu Pendidikan (STKIP) Muhammadiyah, Indonesia \\ Email: usmanbarru@gmail.com,
}

(Diterima: 18 September 2020; direvisi: 03 Desember 2020; dipublikasikan: 07 Desember 2020 )

(C2018 -Bongaya Journal for Research in Management STIEM Bongaya. Ini adalah artikel dengan akses terbuka dibawah licenci CC BY-NC-4.0 (https://creativecommons.org/licenses/by-nc/4.0/).

\begin{abstract}
This research aims to find out if the effect of professionalism variables on employee productivity variables in the Central Bureau of Statistics of South Sulawesi Province. Data collection using primary data obtained from questionnaires using simple random sampling techniques. The population is all employees of the Central Bureau of Statistics of South Sulawesi Province, a total of 90 employees, while the sample taken amounted to 40 respondents. The results of the questionnaire have tested its validity and reliability, and have also testedclassic assumptions in the form of tests of normality, multicollinearity and heteroskedastisitas. The data analysis method uses multiple regression techniques. The results showed that the proposed hypothesis was accepted because it showed positive and significant hypothetical test results, against professionalism variables to employee work productivity variables.
\end{abstract}

Keywords : Professionalism; Employee Work Productivity

\begin{abstract}
Abstrak : Penelitian ini bertujuan untuk mengetahui pengaruh variabel profesionalisme terhadap variabel produktivitas pegawai pada Badan Pusat Statistik Provinsi Sulawesi Selatan. Pengumpulan data menggunakan data primer yang diperoleh dari kuesioner dengan menggunakan teknik simple random sampling. Populasi adalah seluruh pegawai Badan Pusat Statistik Provinsi SulawesiSelatan yang berjumlah 90 pegawai, sedangkan sampel yang diambil berjumlah 40 responden. Hasil angket telah diuji validitas dan reliabilitasnya, serta uji asumsi klasik berupa uji normalitas, multikolinearitas dan heteroskedastisitas. Metode analisis data menggunakan teknik regresi berganda. Hasil penelitian menunjukkan bahwa hipotesis yang diajukan diterima karena menunjukkan hasil uji hipotesis yang positif dan signifikan terhadap variabel profesionalisme terhadap variabel produktivitas kerja karyawan.
\end{abstract}

Kata Kunci: Profesionalisme, Produktivitas Kerja Karyawan

\section{PENDAHULUAN}

Profesionalisme adalah suatu sikap atau keadaan dalam melaksanakan pekerjaan dengan 
memerlukan keahlian melalui pendidikan dan pelatihan tertentu dan dilakukan sebagai suatu pekerjaan yang menjadi sumber penghasilan.

\section{Cara Pengembangan Profesionalisme}

Dalam rangka mengembangkan profesionalisme kerja, tentu saja diperlukan proses pendidikan, pelatihan dan pembelajaran bagi para pegawai. Berdasarkan kategori pegawai, pelatihan dapat berupa program orientasi pegawai baru, pelatihan umum secara ekstensif, pelatihan pekerjaan yang spesifik, praktik standar secara bertahap, pelatihan peralatan dan prosedur operasi. Adapun cara pengembangan profesionalisme dapat dilaksanakan dengan kegiatan-kegiatan berikut ini:

1. Menyelenggarakan kegiatan penataran dan pelatihan terhadap para pekerja yang dilaksanakan secara bertahap dan berkesinambungan.

2. Memberikan kesempatan kepada para pekerja untuk melanjutkan pendidikan ke tingkat lebih tinggi.

3. Mengirim atau menyekolahkan para pekerja pilihan keluar negeri.

4. Menyelenggarakan kegiatan seminar, lokakarya atau workshop yang berkaitan dengan peningkatan kualitas tenaga kerja.

5. Menyediakan fasilitas dan bantuan dana kepada para pekerja yang berprestasi untuk meningkatkan kualitas di bidangnya.

\section{Produktivitas Kerja Pegawai}

Filosofi mengenai produktivitas mengandung arti keinginan dan usaha setiap manusia untuk selalu mengingatkan mutu kehidupan dan penghidupannya. Pandangan filosofis ini memberikan arti dan semangat yang cukup mendalam. Pandangan ini juga memungkinkan setiap orang yang memahaminya untuk memandang kerja, baik secara individual maupun berkelompok dalam suatu organisasi sebagai suatu keutamaan.

Menurut Simanjuntak (2005: 46),definisi operasional adalah unsur-unsur penelitian yang memberitahukan bagaimana mengukur suatu variabel sehingga dengan pengukuran tersebut dapat diketahui indikatorindikator apa saja sebagai pendukung untuk dianalisis kedalam variabel-variabel tersebut. Definisi operasional dalam penelitian ini Variabel bebas (X), profesionalisme diukur dengan indikator, sebagai berikut

1) Kompetensi aparatur yang dimiliki pegawai yang dilihat dari :

a. Pengetahuan (knowledge) dan keahlian (skill) dalam mengerjakan pekerjaan yang dipertanggung jawabkannya.

b. Keterampilan tertentu (spesialisasi kerja) yang dibutuhkan dalam bidang pekerjaan yang dipertanggung jawabkannya.

2) Performansi (performance) dapat diartikan :

a. Adanya target dalam penyelesaian pekerjaan yang diberikan dalam pelayanan kepada masyarakat;

b. Keinginan pegawai untuk meningkatkan kemampuan dan prestasi kerja.

3) Akuntabilitas (accountability) pegawai dilihat dari :

a. Integritas (selalu memegang kode etik) yang diterapkan dalam menjalankan tugas dan pekerjaan;

b. Ketelitian dalam menyelesaikan pekerjaan;

c. Pemungutan biaya pelayanan publik harus sesuai dengan ketentuan perundang-undangan;

\section{Produk pelayanan publik.}

Produktivitas kerja pegawai diukur dengan indikator, sebagai berikut:

1) Beban Pekerjaan, dimensi ini menunjukkan jumlah pekerjaan atau beban pekerjaan yang dihasilkan individu atau kelompok sebagai persyaratan yang menjadi standar pekerjaan.

2) Kualitas Pekerjaan, setiap karyawan dalam perusahaan harus memenuhi persyaratan tertentu untuk dapat menghasilkan pekerjaan yang sesuai kualitas yang dituntut suatu pekerjaan tertentu.

3) Ketepatan waktu, setiap pekerjaan memiliki karakteristik yang berbeda, untuk jenis 
Usman; Yanti, ,Pengaruh Profesionalisme terhadap Produktivitas Pegawaipada Badan Pusat Statistik

pekerjaan tertentu dan harus diselesaikan tepat waktu, karena memiliki ketergantungan atas pekerjaan lainnya.

4) Kehadiran, suatu jenis pekerjaan tertentu menuntut kehadiran karyawan dalam mengerjakannya sesuai waktu yang ditentukan. Kinerja karyawan ditentukan oleh tingkat kehadiran karyawan dalam mengerjakannya.

5) Kemampuan kerja sama, tidak semua pekerjaan dapat diselesaikan oleh satu orang karyawan saja. Untuk jenis pekerjaan tertentu mungkin harus diselesaikan oleh dua orang karyawan atau lebih, sehingga membutuhkan kerja sama antara karyawan sangat dibutuhkan. Kinerja karyawan dapat dinilai dari kemampuannya bekerjasama dengan rekan sekerja lainnya.

Hasil penelitian terdahulu memberikan bukti bahwa profesionalisme kerja yang diukur dengan produktivitas intrinsik dan produktivitas ekstrinsik berpengaruh positif dan signifikan menurut (Elysa Minarni (2017). Hasil tersebut berbeda dengan peneliti lainnya, bahwa profesionalisme kerja berpengaruh negatif dan tidak signifikan terhadap produktivitas kerja pegawai (Lailah Fujianti (2012).

Berdasarkan rumusan masalah yang telah dikemukakan sebelumnya maka hipotesis dalam penelitian ini adalah $\mathrm{H} 1$ Variabel profesionalisme berpengaruh positif dan signifikan terhadap produktivitas kerja pegawai

\section{METODE}

Populasi adalah wilayah generalisasi yang terdiri atas objek/subjek yang mempunyai kualitas dan karakteristik tertentu yang diterapkan oleh peneliti untuk dipelajari dan kemudian ditarik kesimpulannya (Sugiyono, 2013). Populasi dalam penelitian ini adalah seluruh pegawai negeri sipil (PNS) yang bekerja pada kantor Badan Pusat Statistik Provinsi Sulawesi Selatan yang berjumlah 90 orang pegawai. Dan Teknik pengumpulan sampel dalam penelitian ini adalah sampel acaksederhana (simple random sampling). Didalam
Purwanto (2012) menyatakan bahwa sampelacak sederhana (simple random sampling), adalah cara pengambilan sampel dengan memilih semua responden jadi sampel (jenuh), karena sampel yang diambil adalah pegawai tetap yang berada di ruang kerja.

Teknik pengumpulan data yang digunakan dalam penelitian ini menggunakan kuesioner (angket) yaitu teknik pengumpulan data yang dilakukan dengan cara memberikan seperangkat pertanyaan atau pernyataan tertulis kepada responden untuk dijawab. Kuesioner digunakan peneliti untuk mengetahui pengaruh profesionalisme kerja terhadap produktivitas kerja pegawai pada Badan Pusat Statistik Provinsi SulawesI Selatan.

Teknik analisis data yang digunakan untuk menentukan sejauh mana kesamaan antara hasil yang diperoleh dari suatu sampel dengan hasil yang akan didapat pada populasi secara keseluruhan. Jadi statistik inferensi membantu peneliti untuk mencari tahu apakah hasil yang diperoleh dari suatu sampel dapat digeneralisasi pada populasi. Penguji hipotesis dilakukan dengan persamaan regresi berganda, dengan rumus:

$$
Y=\alpha+\beta_{1} X_{1}+e
$$

Dimana :

$$
\begin{array}{lll}
\mathrm{Y} & =\text { Profesionalisme } & \\
\mathrm{X}_{1} & =\text { Produktivitas Kerja } & \text { Pegawai } \\
\alpha & =\text { Konstanta } \\
\beta_{1} & =\text { Koefisien regresi. }
\end{array}
$$

\section{HASIL DAN PEMBAHASAN}

Pengolahan data dalam penelitian ini menggunakan analisis regresi berganda dengan software SPSS versi 22. Sebelum melakukan evaluasi tersebut, peneliti melakukan uji statistik deskriptif.

\section{Hasil Uji Statistik Deskriptif}

Uji deskriptif akan menjelaskan variabel dalam penelitian ini yaitu variabel independen profesionalisme dan variabel dependen yaitu 
produktivitas kerja pegawai. Data yang akan diolah peneliti yaitu data yang didapatkan dari hasil survey dan penyebaran kuesioner pada Badan Pusat Statistik Provinsi Sulawesi Selatan.

Suatu data yang dilihat dari analisis statistik deskriptif yaitu nilai rata-rata dan standar deviasi. Suatu data peneliti dikatakan baik dalam statistik deskriptif jika nilai mean dari setiap indikator lebih besar dari nilai standar deviasinya, sehingga nilai mean merupakan representasi yang baik dari keseluruhan.

Hasil uji statistik deskriptif setelah

dilakukan penelitian diperoleh data sebanyak 40 responden yang merupakan hasil survey dan penyebaran kuesioner pada Badan Pusat Statistik Provinsi Sulawesi Selatan. Hasil olahan data tersebut dapat dilihat pada tabel di bawah ini :

Tabel 1. Descriptive Statistic

\begin{tabular}{|l|r|r|r|}
\hline & \multicolumn{1}{|l|}{ Mean } & $\begin{array}{l}\text { Standard } \\
\text { deviation }\end{array}$ & N \\
\hline $\begin{array}{l}\text { Produktivitas } \\
\text { kerja pegawai }\end{array}$ & 4.0475 & .41447 & 40 \\
\hline Profesionalisme & 4.1425 & .30388 & 40 \\
\hline
\end{tabular}

Variabel Profesionalisme dalam penelitian ini menunjukan nilai mean yaitu4,0475 dan nilai standar deviasi yaitu 0,41447 dari hasil tersebut memberikan penjelasan nilai mean $>$ dari nilai standar deviasi sehingga dapat disimpulkan bahwa tingkat variabel profesionalisme dalam penelitian ini baik digunakan sebagai representasi data. Dan Produktivitas kerja pegawai dalam penelitian ini menunjukan nilai mean yaitu 4,1425 dan nilai standar deviasi yaitu 0,30388 dari hasil tersebut memberikan penjelasan nilai mean $>$ dari nilai standar deviasi sehingga dapat disimpulkan bahwa tingkat variabel produktivitas kerja pegawai dalam penelitian ini baik digunakan sebagai representasi data.

Hasil pengujian regresi ganda dalam penelitian ini dapat dilihat pada tabel 4.16 dibawah ini :

\section{Tabel 2. Analisis Statistik Inferensial}

\begin{tabular}{|c|c|c|c|}
\hline \multirow[b]{2}{*}{ Model } & $\begin{array}{l}\text { Unstandardized } \\
\text { coefficients }\end{array}$ & \multirow[b]{2}{*}{$\mathrm{t}$} & \multirow[b]{2}{*}{ Sig } \\
\hline & B & & \\
\hline (Constant) & -.753 & -1.55 & .129 \\
\hline Profesionalisme & 1.159 & 9.930 & .000 \\
\hline
\end{tabular}

$$
\begin{aligned}
& Y=a+b_{1} X_{1} \\
& Y=-0,753+1,159 X_{1}
\end{aligned}
$$

Hasil dari persamaan regresi tersebut

menunjukkan arah variabel bebas (Independen) yaitu profesionalisme terhadap variabel terikat (Dependen) yaitu produktivitas kerja pegawai. Koefisien X1 bernilai $(1,159)$ dengan nilai sig $0,000<0,05$ sehingga pengaruhnya positif dan signifikan terhadap produktivitas kerja pegawai.

\section{Hasil Uji Hipotesis}

Uji hipotesis merupakan suatu pengujian untuk membuktikan adanya hubungan antara variabel dalam penelitian ini. Uji hipotesis bertujuan untuk mengetahui jawaban sementara terhadap masalah masih praduga karena masih harus dibuktikan kebenarannya sesuai dengan pendapat sementara yang diutarakan peneliti. Uji Parsial (Uji t)

Pengujian ini dilakukan untuk mengetahui pengaruh signifikan profesionalisme terhadap produktivitas kerja pegawai secara parsial dan menjawab hipotesis yang telah disusun oleh peneliti dalam penelitian ini. Dasar pengambilan keputusan dalam uji ini yaitu:

Jika t-hitung > t-tabel dan sig $<0.05$, maka dapat disimpulkan bahwa variabel independen berpengaruh positif dan signifikan terhadap variabel dependen. Jika t-hitung $<\mathrm{t}$-tabel dan sig $>0.05$, maka dapat disimpulkan bahwa variabel independen tidak berpengaruh positif dan signifikan terhadap varibel dependen.

Hasil penelitian menjelaskan bahwa profesionalisme pegawai di kantor Badan Pusat Statistik Sulawesi Selatan berpengaruh terhadap produktivitas pegawai. Hal ini disebabkan karena setiap pegawai secara sadar melaksanakan tugas dan tanggung jawabnya dengan baik dan disiplin. 
Usman; Yanti, ,Pengaruh Profesionalisme terhadap Produktivitas Pegawaipada Badan Pusat Statistik

Mereka merasa wajib untuk menjalankan semua tugas yang diberikan kepada mereka dengan baik tanpa menunggu perintah dari atasan mereka. Disiplin, semangat dan bertanggungjawab terhadap tugas mereka merupakan prinsip yangdi pegang oleh para pegawai dan itu merupakan wujud dari profesionalisme seorang pegawai (Umar, 2018).

\section{DAFTAR PUSTAKA}

Atik Purwandi. 2008. Konsep Kebidanan Sejarah \& Profesionalisme. Jakarta: Kedokteran EGC

Bangun, Wilson. (2012). Manajemen Sumber Daya Manusia. Bandung: Erlangga

Data, \& Tafsir (2018).Pengaruh Kepemimpinan, Motivasi Dan Budaya Organisasi Terhadap Kinerja PegawaiSeiko: Journal of Management \& Business,

Siagian, Sondang P. 2002. Meningkatkan Produktivitas Kerja Pegawai. Jakarta: Rineka Cipta

Ghozali, Imam. 2013. Aplikasi Analisis Multivariate dengan Program SPSS. Edisi Ketujuh. Semarang: Badan Penerbit Universitas Diponegoro

Hamalik, Oemar. 2000. Pengembangan Sumber Daya Manusia, Manajemen Pelatihan Ketenagakerjaan, Pendekatan Terpadu. Jakarta: Bumi Aksara.

Hani, T. Handoko. 2001. Manajemen Personalia dan Sumber Daya Manusia. Edisi 2. Yogyakarta: BPFE

Hasibuan, Melayu. 2000. Manajemen Sumber Daya Manusia. Jakarta: PT. Bumi Aksara.

Kurniawan, Agung. 2005. Transformasi Pelayanan Publik. Yogyakarta: Pembaharuan

Lailah Fujianti. 2012. Pengaruh Profesionalisme Terhadap Komitmen Organisasi dan Kepuasan Kerja Serta Dampaknya Tarhadap Kinerja Akuntan Pendidik. Forum Bisnis dan Keuangan I

Minarni Elysa. 2017. Pengaruh Profesionalisme terhadap Produktivitas Kerja Pegawai pada Kantor Badan Pusat Statistik Kota Medan. Jurnal, Universitas Sumatera Utara.
Moenir, H.A.S. 1992. Manajemen Pelayanan Umum di Indonesia. Jakarta: Bumi Aksara.

Mangkunegara, Prabu, Anwar. 2013. Manajemen Sumber Daya Manusia. Jakarta: Ghalia Indonesia

Payaman, J. Simanjuntak. 2005. Manajemen dan Evaluasi Kinerja. Jakarta: Lembaga Penerbit Fakultas Ekonomi Universitas Indonesia.

Sugiono. 2005. Metode Penelitian Administrasi. Bandung: Alfabeta

Sutrisno, Eddy. 2011. Budaya Organisasi. Jakarta: Kencana Prenada Media Group

Siagian, Sondang P. 2009. Kiat Meningkatkan Profesionalisme Kerja. Jakarta: Rineka Cipta 